\title{
Finansal Raporlarm Kalitesine Etki Eden Ülkeye Özgü Faktörler
}

\author{
Gürol DURAK * \\ Eymen GÜREL ${ }^{* *}$
}

\section{ÖZET}

Finansal raporlamanın amacının ekonomik karar alıcılara ihtiyaç duydukları bilgilerin sunulması olduğu göz önünde bulundurulduğunda, yüksek kalitede finansal raporların sunulmast muhasebe bilgi sisteminin temel amaçlart arasında yerini almaktadır. Araştırmacılar açısından da finansal raporların, özellikle kazançların, kalitesi konusu oldukça dikkat çekmekte ve pek çok araştırmacı bu konuya yönelmektedir. Genel olarak Uluslararası Finansal Raporlama Standartları'na geçiş ile finansal raporlama kalitesinde artış gözlenmesi beklenmesine rağmen, UFRS ile uyumlu finansal raporlar hazırlanmasinın tek başına bunu sağlayamayacă̆ konusunda literatürde görüş birliği bulunmaktadır. Çalışmada finansal raporlama kalitesi kavramının tanımlanması ve finansal raporların kalitesini etkileyen faktörlerin açıklanması amaçlanmıştır. Bu doğrultuda, yapılan çalışmalar incelenmiş ve finansal raporlama üzerinde etkili olduğu sonucuna ulaşılan faktörler açıklanmıştır. Söz konusu çalışmalar, piyasaların gelişmişlik düzeyi, politik sistemin işleyişi, ülkelerin yasal sistemleri, vergi sistemleri ve kültür gibi ülkelere özgü etkenlerin finansal raporların kalitesi üzerinde etkisi bulunduğu sonucuna ulaşmaktadırlar.

Anahtar Kelimeler: Finansal Raporlama, UFRS, Kültürel Değerler, Ülkelere Özgü Etkenler.

JEL Sinuflandırması: M41, M48.

\section{Country Specific Factors Affecting Financial Reporting Quality}

ABSTRACT

When it is considered that the aim of financial reporting is to present the information decision makers need, providing high quality financial reports is one of the main objectives of accounting information system. The subject of financial reporting quality, especially of earnings, has attracted much attention of the researchers; thus, the studies have focused on this subject. Although financial reporting quality is expected to increase with the transition to International Financial Reporting Standards (IFRS), it is a generally accepted fact in the literature that preparation of IFRS adopted financial reports is not enough itself. The main objective of this study is to define the concept of financial reporting quality and to explain the factors affecting financial reporting quality. In this context, literature is reviewed and indicated factors are explained in more detail. The results of studies show that, country-level factors such as level of development in the financial markets, administration of political system, legal systems, taxation systems and culture affect the quality of financial reporting.

Keywords: Financial Reporting, IFRS, Cultural Values.

Jel Classification: M41, M48.

\footnotetext{
*Yrd. Doç Dr. Gürol DURAK, Yaşar Üniversitesi, İşletme Bölümü, gurol.durak@yasar.edu.tr

** Yrd.Doç Dr. Eymen GÜREL, Muğla Sıtkı Koçman Üniversitesi, Uluslararası Ticaret ve Finansman Bölümü, gureleymen@yahoo.com
} 


\section{GíRiş}

İşletmeler faaliyetlerinde kullanmak üzere varlıklara ihtiyaç duydukları gibi, bu varlıkların edinilmesinde kullanacakları finansman kaynağı olarak kendi ortaklarından ya da işletme dışındaki ilişkili taraflardan fon bulmaları gerekmektedir. İşletmelerin yatırım yapılabilir ya da borç verilebilir durumda olup olmadıklarını bu taraflara bildirmelerinin tek yolu ise hazırladıkları finansal raporlar olmaktadır. Zira işletme dışındaki tarafların işletme ile ilgili tek bilgi kaynağı bu finansal raporlardır.

En önemlileri oldukları kabul edilmekle birlikte, işletmeden bilgi bekleyen paydaşlar sadece yatırımcılar ve borç verenler değildir. Pek çok paydaş işletmelerin sundukları raporları kullanarak kararlar almaktadır. Örneğin, vergi otoriteleri işletmelerin vergi borçlarının belirlenmesi için muhasebe bilgisine ihtiyaç duyarken, işçi sendikaları gibi sivil toplum örgütleri üyelerinin haklarını koruyabilmek üzere finansal bilgi elde etme isteğindedirler. Öte yandan, işletmenin rakipleri, tedarikçileri, müşterileri gibi pek çok diğer kullanıcı da işletme bilgilerine ihtiyaç duyan ilişkili tarafları oluşturmaktadırlar.

\section{FINANSAL RAPORLAMA KALITESI}

Finansal bilgi kullanıcılarının ihtiyaçlarına göre finansal raporlama kalitesi bir bütün olarak finansal rapor setinin kalitesi ya da sadece kazanç kalitesi olarak ele alınabilmektedir. Yöneticiler ve yatırımcılar açısından işletmenin performansının değerlendirilmesi konusunda birincil bilgi kaynağı işletmenin kazancıdır. Aynı zamanda, finansal analistler de sunulan kazanç rakamını temel gösterge olarak kabul etmektedirler (Ertan, 2011: 22). Bu bağlamda, Dechow ve Schrand (2004) kazanç rakamının işletmenin değerinin düzgün şekilde dönemselleştirebildiği ölçüde kaliteli sayılacağını savunmaktadırlar. Diğer bir ifadeyle, raporlanan kazanç rakamı mevcut performansı doğru yansıttı̆̆ı, gelecekteki performansın tahmin edilmesinde yardımcı olduğu ve işletme değerinin belirlenmesine temel alınabildiği ölçüde kalitelidir. Schipper ve Vincent (2003)'a göre, kazanç rakamı işletme sahiplerinin servetlerindeki değişikliği gerçeğe uygun şekilde yansıtırsa kaliteli sayılmaktadır. Ayrıca, birçok çalışmada kaliteli raporlanmış kazanç, gelecek nakit akışları ile yüksek derecede ilişkiye sahip olan kazanç olarak tanımlanmaktadır (Cohen, 2003: 3).

Gerek finansal raporların gerekse kazancın kalitesi açısından finansal raporlama kalitesinin odağında ilişkili tarafların bilgilendirilmesi konusunun olduğu anlaşılmaktadır. Bu bağlamda, işletmelerin finansal raporlarının kalitesinin belirlenmesi finansal piyasalar açısından da işletmeler için olduğu kadar önem arz etmektedir. Bu nedenle, finansal raporların ve/veya kazancın kalitesi üzerine geniş bir literatür oluşmuştur. Araştırmacılar tarafından finansal raporlama kalitesi "kazanç yönetimi derecesi", "ihtiyatlılık derecesi" ve "tahakkuk kalitesi” gibi olgular 1şı̆̆ında değerlendirilmektedir (Choi ve Pae, 2011:409). Öte yandan, kazanç kalitesine ilişkin Francis vd. (2006) 7 adet ölçüt belirlemektedir. Bu ölçütler muhasebe-temelli ve piyasa-temelli ölçütler olarak iki sınıfta ele alınmaktadır. Muhasebe temelli ölçütler "tahakkuk kalitesi", "süreğenlik", "tahmin edilebilirlik" ve "değişkenlik" 
olmakla birlikte muhasebe raporlarından elde edilen verilere dayanmaktadırlar. Piyasa temelli ölçütler ise "değere ilişkinlik", "zamanında sunum" ve "ihtiyatlılık" olarak belirlenmektedir. $\mathrm{Bu}$ ölçütler hem muhasebe raporlarından hem de piyasa verilerinden elde edilen bilgilere dayanmaktadırlar.

Tahakkuk Kalitesi: Kazanç rakamını oluşturan iki bileşenden nakit akışları, hali hazırda kesinleşmiş rakamlar oldukları için, tahakkukların kalitesinin belirlenmesi aynı zamanda kazanç rakamlarının da kalitesinin belirlenmesi anlamına gelmektedir. Tahakkuklar ise nakit akışlarına dönüştükleri ölçüde kaliteli sayılmaktadırlar (Dechow ve Dichev, 2002: 38; Francis vd., 2006: 270).

Süreğenlik: Kazancın süreğenlik özelliğine sahip olması istenen bir durumdur. Kazancın süreğen olması durumunda, açıklanan kazanç tutarının izleyen dönemlerde de mevcut olacağı ve geleceğe yönelik bilgiler sunabileceği düşünüldüğünde süreğenliğin artmasıyla kazancın kalitesinin de arttığının kabul edilmesi mümkündür.

Tahmin Edilebilirlik: Bu özellik geçmiş dönemlerde raporlanan kazanç performansının geleceğe yönelik kazancın tahmin edilmesinde kullanılabilir olması şeklinde ifade edilebilmektedir. Tahmin edilebilirlik bilginin ihtiyaca uygunluk niteliğine sahip olmasının ön koşullarından olduğu için raporlama kalitesi ile doğru orantılı olduğunun savunulması mümkündür.

Düzlük: Yöneticilerin gelecekte oluşacak kazançlara ilişkin özel bilgileri de dönem kazancının uyumlaştırılması için kullanması nedeniyle raporların bilgilendirme özelliğinin arttığı ve dolayısıyla finansal raporlama kalitesine katkı yapıldığı görüşü bulunmaktadır (Demski, 1998: 275). Bu durum düzlük özelliğinin istenilen bir özellik olduğunu işaret etmektedir.

Değere Illişkinlik: Kazanç rakamının hisse senedi fiyatındaki değişimleri açıklama yeteneği şeklinde ifade edilmektedir. Bu nedenle yüksek olması istenen bir durumdur (Barth vd., 2001: 481).

Zamanında sunum: Zamanlılık, kamuya açık bilginin (iyi/kötü haber) muhasebe karında yansıtılma hızını ifade etmektedir. Muhasebe karının temel görevinin, hisse senedi getirisi ile ölçülen ve piyasa değerindeki değişimi ifade eden, ekonomik karı yansıtmak olduğu düşünüldüğünde (Ball vd., 2000:7), zamanında sunumun bilginin vazgeçilmez özelliklerinden olduğunu savunmak mümkündür.

İhtiyatlılık: İhtiyatlılık da kamuya açık bilgilerin/haberlerin finansal tablolara yansıtılma zamanlılığı ile ilgilenmektedir; ancak kötü haberin tablolara yansıtılması için olası duruma gelmesinin yeterli olmasına karşın, iyi haberin yansıtılabilmesi için kesinleşmesinin beklenmesi gerektiğini ifade etmektedir. Zamanlılık ve ihtiyatlılık, birlikte şeffaflık olarak kabul edilebilmekte ve kazanç rakamının sahip olması istenen özellikler arasında sayılmaktadırlar (Ball vd., 2000:8). 
Literatürde kullanılan bu ölçütler sunulan bilgilerin kullanım amaçları doğrultusunda ne derece yetkin ve tam olduğunun belirlenmesi amacıyla seçilen göstergelerdir. Bilginin kalitesi ile sağladığı faydanın doğru orantılı olduğu düşünüldüğünde, kaliteli raporlamanın bilgiyi tam olarak sunması da gerekli özelliklerden birisi olmaktadır. Bu bağlamda, kaliteli finansal raporlar işletme yöneticileri ile işletme dışındaki paydaşlar arasındaki bilgi asimetrisini azaltmaktadırlar. Azalan bilgi asimetrisi ile daha şeffaf raporlama sağlanmış olmakta ve belirsizliğin ortadan kalkması işletmelerin risk primlerini azalttığı için sermaye maliyetleri de düşmektedir (Cohen, 2003:16; Gençoğlu ve Ertan, 2012:5). Böylece işletmelerin finansman bulmaları kolaylaşmakta, firma değeri artmakta ve rekabet konusunda öne çıkabilmektedirler. Diğer bir ifadeyle, finansal raporlama kalitesi işletmenin sermaye piyasasından elde edeceği getiri ile doğru orantıll, sermaye maliyeti ile ters orantılıdır (Cohen, 2003:16).

Kaliteli finansal raporlamanın işletmelere sağladığı faydalar düşünüldüğünde, işletmelerin mümkün olan en yüksek kalitede raporlama yapma eğiliminde olacakları varsayılsa bile, bilginin elde edilmesi ve sunulmasına ilişkin maliyetler nedeniyle gerçek hayatta durum böyle olmamaktadır. Yüksek kalitede hazırlanan finansal raporlar rakiplere daha fazla bilgi sunduğu için rekabet açısından dezavantaj yaratmaktadır. Dolayısıyla, tescil maliyetlerinin değerlemeye ilişkin faydaları aştı̆̆ durumlarda işletmelerin daha az bilgi raporlamaları beklenmektedir. Bu durumda finansal raporlama kalitesi düşmektedir (Cohen, 2003:17). Benzer şekilde, Wagenhofer (1990) da açıklama derecesinin sunulacak bilginin içeriğinden, politik maliyetlerden ve rakiplerin piyasaya girme ihtimalinden etkilendiğini belirtmektedir.

Baiman ve Verrecchia (1996) bilgi sunmanın maliyetleri ile faydalarını karşılaş̧ırdıkları çalışmalarında, sunulan bilgilerin bir yandan sermaye maliyetini düşürürken, diğer yandan yöneticilerin içeriden bilgilendirme sonucu elde ettiği faydayı azalttığını; bu nedenle, yöneticilerin bilgi sunma konusunda ikilem yaşadıklarını savunmaktadırlar. Diğer bir ifadeyle, işletmeler bilgi sunarken en uygun bilgi seviyesini belirlemek üzerine odaklanmakta ve bazı durumlarda finansal raporlama kalitesini düşürebilmektedirler. Bu gibi durumlarda yatırımcıların korunması konusu ön plana çıkmaktadır.

Görüldüğü gibi yapılan çalışmalardan, finansal raporlamanın kalitesinin sağlanması açısından genel olarak sisteme etki eden işletme üstü faktörlerin etkili olduğu sonucuna ulaşılmaktadır. Bu nedenle, çalışmada finansal raporlama kalitesi üzerinde etki eden ülkeye özgü faktörler üzerinde durulmaktadır.

\section{FINANSAL RAPORLAMA KALITESINİ ETKILEYEN ÜLKEYE ÖZGÜ FAKTÖRLER}

Raporlayan işletmelerin finansal raporlarının kalitesi üzerinde işletmeden bağımsız şekilde etkide bulunan ve sistemden kaynaklanan etkiler ülkeye özgü faktörler olarak ele alınmaktadır. İşletmenin faaliyet gösterdiği ülkenin finansal piyasasının gelişmişliği, ülkedeki 
mevcut politik ve yasal sistem, ülkenin kültürü, uygulanan muhasebe standartları, ülkede muhasebe mesleğine verilen önem ve sosyal ve ekonomik koşullar gibi işletmenin müdahale edemeyeceği sistematik faktörler bu sınıfta yer almaktadırlar.

\subsection{Kültür}

Kültürel özelliklerin ülkedeki muhasebe uygulamalarını ve dolayısıyla finansal raporlama kalitesini etkileyeceği savunulmaktadır (Gray, 1988:3). Bu doğrultuda Gray (1988) Hofstede'nin kültür sınıflandırmasını kullanarak muhasebe değerlerini şu şekilde sınıflandırmaktadır (Gençoğlu ve Ertan, 2012:6):

- $\quad$ Profesyonellik ya da Yasal Kontrol: Bireysellik veya belirsizlikten kaçınma özelliği ile ilişkilendirilmektedir. Muhasebe uygulamalarında yasal zorunluluklara mı yoksa mesleki yargıya mı öncelik verildiğinin bir ölçütüdür. Muhasebe uygulamalarındaki esneklik profesyonellik ile artmaktadir.

- $\quad$ Tekdüzen ya da Esneklik: Tekdüze muhasebe uygulamalarının ya da esnek, duruma özel uygulamaların tercih edilmesi durumunu işaret eden kültürel değerdir. Belirsizlikten kaçınan, otorite mesafesi yüksek ve kolektif toplumların tekdüze muhasebe uygulamalarını tercih etmesi beklenmektedir.

- $\quad$ Ihtiyatlılık ya da Iyimserlik: Risk alma eğilimi ile ilişkili değerlerdir. Belirsizlikten kaçınma düzeyi ile ihtiyatlılık derecesinin doğru orantılı olduğu savunulmaktadır.

- Gizlilik ya da Seffaflı: Finansal bilgilerin işletme içinde tutulması ya da dışarıya sunulması arasındaki tercihi yansıtan kültürel değerlerdir. Belirsizlikten kaçınan toplumlarda gizlilik ön planda tutulmaktadır. Otorite mesafesi yüksek toplumlarda da güç dağılımındaki eşitsizliğin korunması için gizlilik tercih edilmektedir.

Gray'in (1988) kültürün muhasebe uygulamalarına etkisi üzerine kurduğu hipotez Askary ve Yazdifar (2008) tarafından Türkiye üzerinde test edilmiş ve ülkemizde, belirsizlikten ve riskten kaçınma yönündeki eğilim nedeniyle, ihtiyatlı ve tekdüze muhasebe uygulamalarının tercih edildiği sonucuna ulaşılmıştır. Ayrıca, finansal raporlarda şeffaflık sağlanması ve muhasebe uygulamalarında mesleki yargının ön planda tutulması yönünde bir düşüncenin hakim olduğu belirlenmiştir (Gençoğlu ve Ertan, 2012:8).

Finansal raporlama açısından kültürün etkileri yasal sistemler veya sermaye piyasaları gibi dışsal etkilere göre daha dolaylı kalmaktadır. Muhasebe çevresini analiz ederken yasal sistemler, kurumsal finansman ve vergi sistemleri gibi daha doğrudan potansiyel etkileri göz önünde bulundurmak gerekmektedir. $\mathrm{Bu}$ etkiler kültürle birleşerek o ülkedeki finansal raporlama şeklini ve muhasebe mesleğinin gelişimini etkilemektedirler.

\subsection{Politik Sistem}

İşletmeler ile faaliyet gösterdikleri ülkelerdeki mevcut otoriteler arasındaki ilişkiler de finansal raporlama kalitesi üzerinde önemli derecede etkiye sahip olabilmektedir. Özellikle 
politikacılar bağlantıda oldukları işletmeleri koruduklarında, bu işletmelerin, sundukları finansal bilgilerin kalitesi konusunda daha az dikkatli oldukları varsayılmaktadır (Chaney vd., 2007:6). Chaney vd. (2007) tarafından yapılan çalışmanın bulguları, finansal raporlama kalitesi düşük olan işletmelerden sadece politik bağlantısı olmayan işletmeler için borçlanma maliyetlerinde bir artış gözlendiğini ortaya koymaktadır. Politik bağlantıları olan işletmelerin daha düşük kalitede raporlar sunmalarından dolayı cezalandırılmadıklarının söylenmesi de mümkündür. Correia (2010) muhasebe kalitesi düşük olan işletmelerin politik harcamalarının diğerlerine oranla daha yüksek olduğunu ve bu harcamaların özellikle yanlış raporlama yapıldığı dönemlerde kongrenin sermaye piyasaları ile ilgili komite üyelerine yapıldığını belirtmektedir (Chen vd., 2008:9).

Yu ve Yu (2008) lobi faaliyetlerinde bulunmanın hilenin belirlenmesini geciktirdiğini belirtmektedirler. Çalışmaya göre, hakkında dava açılan işletmeler için hile yıllarında lobi faaliyetlerinde artış gözlenmektedir.

Ayrıca, kamulaştırmanın ve yolsuzlukların yoğun olduğu ülkelerde, sosyal ve politik incelemelerden kaçınmak için sözleşmelerin gizlice tamamlanması olasılığı artmaktadır. Bu ülkelerde, finansal tablolar bilgi kaynağı olarak oldukça az kullanılmakta ve bilgiye olan talebin azlığı da muhasebe kalitesinin düşmesine neden olmaktadır (Gençoğlu ve Ertan, 2012:9).

\subsection{Finansal Piyasaların Gelişmişlik Düzeyi}

Günümüze kadar yapılan çalışmalarda gelişmiş bir sermaye piyasası bulunan, yayılmış ortaklık yapısına sahip, güçlü yatırımcı koruması ve yasal yaptırımları olan ülkelerdeki işletmelerin kazanç yönetimine daha az başvurdukları belirlenmektedir (Leuz vd., 2003: 516). $\mathrm{Bu}$ durumu gelişmiş piyasalardaki bilgi talebinin yoğun olması sonucu yöneticilerin finansal raporların kalitesine verdikleri önemin de arttığı yönünde açıklamak mümkündür.

Diğer bir ifadeyle, finansal raporlamanın kalitesinin artması yoluyla yatırımcıların sermaye piyasasına girişleri sağlanmakta, yatırımcı portföyünün ve sayısının artışı ile birlikte hisseler daha geniş kitlelere yayılabilmektedir (Fan ve Wong, 2002: 418; Luez vd., 2003: 514; Narktabtee ve Patpanichchot, 2011). Bunun sonucunda daha farklı kesimlerden ve daha yoğun şekilde gelen bilgi talepleri nedeniyle işletmeler finansal raporlarının kalitesini yüksek tutmaları yönünde baskı altında bulunmaktadırlar. Ayrıca, işletmelere duyulan güvenin sarsılmaması ve hisselerinin değer kaybetmemesi açısından da sunulan bilgilerin kaliteli olması gerekmektedir.

Gelişmiş bir sermaye piyasası olmanın önkoşulunun yatırımcıların korunması olduğu kabul edilirse, kalitesi düşük finansal raporlar sunmanın işletmelere yasal ve sosyal yaptırımları olacağının söylenmesi mümkündür. Özetle, finansal raporlamanın kalitesi ile sermaye piyasalarının gelişmişlik derecesi arasında pozitif bir ilişki bulunmaktadır. 


\subsection{Sosyal ve Ekonomik Koşullar}

Bir ülkede ekonominin gelişmiş olması işletmelerin yeni yatırımlar yapabilmek üzere finansman bulma ihtiyacını artıracaktır. Bu süreç dahilinde, daha iyi koşullarda finansman bulma isteğinin söz konusu işletmeleri finansal raporlarının kalitelerini yüksek tutmaları yönünde teşvik etmesi beklenmektedir (Gençoğlu ve Ertan, 2012:10).

Enflasyon da finansal raporlama kalitesi üzerinde etkili olan ekonomik faktörlerden biridir. Zaman içerisinde paranın alım gücünde meydana gelen değişimin göz önünde bulundurulmaması, hatta bulundurulsa bile söz konusu etkinin bütün finansal tablo kalemlerinde aynı derecede etkili olmaması, raporlanan bilgileri ihtiyaca uygunluktan uzaklaştırmaktadır. Diğer bir ifadeyle, bilginin kullanıcıları açısından kötü kararlar alınmasına neden olabileceği savunulmaktadır (Gücenme, 2005: 35). Ayrıca, enflasyon muhasebesi gibi bir kavramın mevcudiyeti, enflasyonun finansal raporların kalitesi üzerindeki etkilerinin yadsınamaz olduğunu ve ülkelerin bu etkilerin olumsuz etkilerini azaltmak üzere farklı muhasebe uygulamalarına başvurduklarını göstermektedir.

Finansal raporlama kalitesini etkileyen bir diğer ekonomik faktör ekonomik krizlerdir (Gençoğlu ve Ertan, 2012: 17). Ekonomik krizler sonucunda yatırım hacminde meydana gelen daralmadan en az seviyede etkilenmek üzere işletme yöneticileri, kazanç yönetimi uygulamaları yoluyla, finansal raporlarını iyi gösterme eğiliminde olabilmektedirler. $\mathrm{Bu}$ durum finansal raporlama kalitesinin azalmasına neden olmaktadır.

Ekonomik faktörlerin yanı sıra ülkenin sosyal özelliklerinin de finansal raporlama üzerinde etkili olması beklenmektedir. Ülkedeki eğitim seviyesi göz önünde bulundurulması gereken faktörlerden birisidir. Daha yüksek seviyede eğitim almış toplumlar bilgi taleplerini daha karmaşık muhasebe sistemleri kullanarak gidermektedirler. Muhasebe standartlarının ve uygulamalarının daha karmaşı hale gelmesi, onların yorumlanması ve uygulanmasının da daha eğitimli kişiler tarafından yapılması ihtiyacını beraberinde getirmektedir. Acar ve Özçelik (2011) muhasebe bilgilerinin kalitesini etkileyen kritik başarı faktörlerinin algılanma düzeylerini ölçmeyi amaçladıkları çalışmalarında eğitimin en fazla önem verilen operasyonel başarı faktörlerinden birisi olduğu sonucuna ulaşmaktadırlar. Özetle, eğitim seviyesindeki artışın finansal bilgilerin kalitesinde de artışa yol açacağı ortaya çıkmaktadır.

\subsection{Muhasebe Altyapısı ve Muhasebe Meslek Örgütleri}

Ülkelerin muhasebe sistemlerinde ortaya çıkan yeni ihtiyaçlar çerçevesinde finansal raporlama kalitesini yüksek tutmak amacıyla bazı yenilikler olabilmekte ve gerek bu yeniliklerin getirilmesinde gerekse meslek mensuplarının bu yeniliklere adaptasyonunun sağlanması sürecinde muhasebe meslek örgütleri başrolü üstlenmektedir. Söz konusu meslek örgütleri ülkede muhasebe uygulamaları ile ilişkili düzenleme ya da yasaların hazırlanma sürecine dahil olarak da yapılan yeni düzenlemelerin amaca uygun şekilde hazırlanmasını temin etmektedirler. 
Meslek mensuplarının etik değerlere bağlı kalması açısından da söz konusu örgütler kurullar oluşturmakta ve faaliyetlerde bulunmaktadırlar. Mesleki yetkinliğin sağlanması için gerekli eğitimlerin sunulması yoluyla ülkenin muhasebe sisteminin kalitesinin korunması yönünde önemli işler gerçekleştirmektedirler.

\subsection{Rekabet Ortamı}

İşletmenin faaliyet gösterdiği sektördeki rekabet işletmelerin finansal bilgi açıklama kararlarında etkili olmaktadır. Bazı modeller rekabetin artmasının raporlama kalitesini de artıracağını savunmaktadırlar. Darrough ve Stouhgton (1990) mevcut rakiplerin rekabetçi piyasalarda daha bilgilendirici açıklamalar yaparak piyasaya gelecekte olabilecek girişleri engelleyebileceğini savunmaktadırlar.

Öte yandan, Verrecchia (1983) mevcut rekabetin işletmenin raporlama isteğini azalttığını ve bu nedenle rekabetçi piyasalarda finansal raporlamanın daha az bilgi içerdiğini belirtmektedir. Yöneticiler rekabetin yüksek olduğu piyasalarda rakiplerine bilgi vermekten kaçınmakta ve bu rekabetten kaynaklanan tescil maliyetlerinden kendilerini bu şekilde korumak istemektedirler. Ancak piyasaya giriş için engellerin yüksek olduğu durumlarda, tescil maliyetleri görece daha az olmaktadır. Örneğin, sermaye yoğun bir endüstrinin piyasaya girişin zor olduğu bir endüstri olduğu kabul edilmektedir (Piotroski, 2003: 26). Bu nedenle sermaye yoğun olmak ile finansal raporlama kalitesi arasında doğru orantı beklenmektedir. Cohen (2003) de çalışmasında sermaye yoğun işletmelerin sundukları muhasebe bilgilerinin gelecekteki nakit akışlarını daha iyi tahmin ettiğini belirlemektedir. Sektörün sermaye yoğun olması sektöre girişi zorlaştırmakta ve bu nedenle sektörde faaliyet gösteren işletmelerin tescil maliyetleri düşük olmaktadır. Bu nedenle, daha fazla bilgi sunmaktan da çekinmemektedirler.

\subsection{Yasal Sistem}

İşletme içindeki ve dışındaki ilişkili taraflar arasındaki çıkar çatışmalarının yöneticileri işletme performansını olduğundan farklı göstermeleri yönünde teşvik ettiği savunulmaktadır (Leuz vd., 2003: 520). Yöneticiler raporlanan kazanç rakamlarını artırmak ya da iyi performans gösterilen yılların kazançlarını izleyen yıllarda kullanılmak üzere saklayarak karı uyumlaştırmak için finansal raporlar üzerinde manipülasyon yapabilmektedirler. Öte yandan, yasal sistem yöneticilerin kendi çıkarları doğrultusunda çalışmalarını engelleyebilmek üzere, onları disiplin altında tutabilmeleri için yatırımcılara bazı haklar tanımakta ve böylece yatırımcıları korumaktadır (Dyck ve Zingales, 2002: 30). Yasal sistem raporlamaya ilişkin ihtiyaç duyulan kuralları, yatırımcıların korunma derecesini belirleyen zorlayıcı kanun maddelerini ve yöneticilerin çıkarcı davranışları ve azınlık pay sahiplerinin haklarını kullanmaları durumunda karşılaşacakları yaptırımları ${ }^{1}$ içermektedir. Söz konusu yaptırımlar,

\footnotetext{
1 Saudagaran ve Diga (2000), yasaların uygulanmasına ilişkin mekanizmaları caydırıcı (ex-ante) uygulama mekanizmaları ve cezalandırıcı (ex-post) uygulama mekanizmaları olarak ikiye ayırmıştır. Caydırıcı
} 
yöneticilerin ya da büyük hissedarların kendi çıkarları doğrultusunda çalışmaları sonucunda katlanacakları maliyetleri ortaya koyarak hatalı raporlama yapmalarını engellemektedir. $\mathrm{Bu}$ durum, finansal raporlamanın kalitesinin artmasına neden olmaktadır (Luez vd., 2003: 515; Gençoğlu ve Ertan, 2012: 17).

Literatürde yasal sistemler ortak hukuk sistemi (common-law) ve yasalara dayalı hukuk sistemi (code-law) olmak üzere iki sınıfta ele alınmaktadır. Ortak hukuk sistemi, ilke bazlı muhasebe uygulamalarını içeren ve dolayısıyla olaya özgü çözümler sunan bir sistemdir. Öte yandan, yasalara dayalı hukuk sistemi kural bazlı olarak kabul edilmekte; konulan genel kuralların bütün olaylara aynı şekilde uygulanması gerekmektedir. İlke bazlı olması nedeniyle, ortak hukuk sistemine sahip ülkelerde sunulan bilgilerin olayların özünü daha iyi yansıtması beklenmekle birlikte, genel kuralların olmaması ve yöneticilerin takdir yetkilerini kullanmaları sonucu elde edilen bilgiler olmaları nedeniyle finansal bilgi kalitesinin düşük olması ihtimali de bulunmaktadır².

Ülkelerin sahip oldukları yasal sistemler, o ülkelerde faaliyet gösteren işletmelerin finansman tercihleri üzerinde de belirleyici olmaktadır. Ortak hukuk sistemine sahip ülkelerde birincil finansman kaynağı sermaye piyasaları iken, yasalara dayalı hukuk sistemine sahip ülkelerde bankalardan finansman ilk tercih olmaktadır. Bu durum, ortak hukuk sistemleri altında yatırımcıların daha fazla korunmasını gerektirmektedir. La Porta ve Lopez De Silanes (1998) ve d'Arcy (2000) de çalışmalarında ortak hukuk sistemindeki ülkelerde yatırımcıların diğer ülkelerdekine göre daha fazla korunduğunu ortaya koymaktadırlar. Diğer taraftan, yasalara dayalı hukuk sistemine sahip ülkelerde işletmelerin çoğunluğu bankalar ve hükümet tarafından yüksek derecede baskı altında tutulmakta ve hatta bu paydaşlar yönetime karışabilmektedirler. Ayrıca, finansal bilginin en önemli kullanıcıları olmaları beklenen bankalar ve hükümet, ihtiyaçları olan bilgileri doğrudan işletmeden sağlayabilecekleri için, söz konusu işletmelerin finansal raporlama kalitesine sahip olmasına da kesin gözle bakılamamaktadır. Aynı durum denetim için de geçerlidir (Nobes ve Parker, 2008: 120). Ortak hukuk sistemine sahip ülkelerde ise, işletmelerin finansal raporlarını işletme dışındaki, bilgiye doğrudan ulaşımı olmayan taraflara sunmalarından dolayı, işletmenin üzerindeki tam açıklama, denetim ve gerçeğe uygun sunum baskısı yüksek olmakta, diğer bir ifadeyle, finansal raporlama kalitesinin yüksek olması beklenmektedir. Jaggi ve Low (2000) ortak hukuka dayalı finansal raporlama yapan ülkelerde açıklama miktarının daha fazla olduğunu; Bushman ve Piotroski (2006) ise bu ülkelerde zararların finansal raporlara daha hızlı yansıtıldıklarını belirlemektedir.

Özetle, kredi yoluyla finansmana ağırlık veren ülkelerde denetlenmiş finansal tablolara olan talebin yoğun olmaması nedeniyle, finansal raporlar daha çok hükümetin istekleri

mekanizmalar, standartlara uyumu destekleyen teşvik eden uygulamaları, cezalandırıcı uygulamalar ise uyumu zorlayan ve uyumsuzlukları cezalandıran uygulamaları kapsamaktadır (Gençoğlu ve Ertan, 2012).

2 İlkeler, içinde bulunulan duruma göre, yorumların da eklenebileceği temel nitelikte prensipleri, kurallar ise ilkelere göre yorum gerektirmeyen, katı, kesin hükümleri ifade etmektedir (Balsarı ve Dalkılıç, 2007). 
doğrultusunda ya da vergi matrahının belirlenmesine yönelik olarak şekillenmektedir. Sonuç olarak, vergi konuları muhasebede ağırlık kazanmaktadır. Öte yandan, sermaye piyasası odaklı ülkelerde, muhasebe, piyasanın ihtiyaçlarını karşılamaya önem vermektedir. Bu nedenle, kurallar vergi alanının dışına çıkmaktadır. Bu durumda iki çeşit muhasebe kural seti ortaya çıkmaktadır: birisi finansal raporlama ağırlıklı, diğeri ise vergilendirme ağırlıklı.

\subsection{Vergi Sistemi}

Muhasebe uygulamalarının vergisel bakış açısı ile organize edilmesi ya da düzenlemelerin vergi odaklı yapılması ülkede finansal raporlama kalitesini düşürücü bir etkidir. Bunun nedeni, vergi odaklı muhasebenin finansal bilgi kullanıcılarının bilgi ihtiyaçlarından çok vergi otoritelerinin vergi matrahının belirlenmesi yönündeki ihtiyaçlarını karşılamak üzere kullanılmasıdır. Bu tür muhasebe sistemlerinde vergi oranlarının yüksek ya da düşük olması finansal raporlar üzerinde yöneticilerin manipülasyon yapma olasılığı ile doğrudan ilişkili olmaktadır.

Ülkemizde 1956 yılından 2011'e kadar muhasebe ile ilgili düzenlemelerin, kuralların ve yaptırımların sadece Vergi Usul Kanunu'nda (VUK) yer alması nedeniyle, muhasebe uygulamalarının vergi mevzuatı çerçevesinde yürütülmesine sebep olmuştur.

\subsection{Muhasebe Standartları}

Literatürdeki çalışmalar muhasebe bilgisinin kalitesinin uygulanan muhasebe standartlarına göre değiştiğini (Jara vd., 2011:181) ve UFRS ya da Amerikan muhasebe standartlarını uygulayan işletmelerin raporlama kalitelerinin yerel muhasebe standartlarını uygulayan işletmelerin raporlama kalitelerine göre daha yüksek olduğunu belirtmektedirler (Barth vd., 2008: 472). Ayrıca, Christensen vd. (2008) tarafından yapılan çalışmada, gönüllü olarak UFRS uygulayan işletmelerin finansal raporlama kalitesinde artış gözlenirken, UFRS'yi zorunlu olarak uygulayan işletmeler için böyle bir artışa ilişkin kanıt bulunamamaktadır. Öte yandan, Jeanjean ve Stolowy (2008) UFRS'ye geçiş ile birlikte İngiltere ve Avustralya' da kazanç yönetimi uygulamalarının yaygınlığının azalmadığını, hatta Fransa'da artırdığını belirlemekte, dolayısıyla UFRS'ye geçişin muhasebe bilgi kalitesini geliştirmediğini savunmaktadırlar (Nkundabanyanga vd., 2013:73). Callao ve Jame (2010) de UFRS'ye geçiş ile birlikte kazanç yönetiminde artış olduğunu belirtmektedirler.

UFRS ilke bazlı olarak nitelendirilmekte ve savunucuları UFRS ile daha şeffaf ve daha karşılaştırılabilir bilgiler sunulduğunu savunmaktadırlar (Zarb, 2006: 31). Öte yandan, UFRS'nin ilke bazlı standartlar olması yöneticilerin fırsatçı davranışlarda bulunmasına da imkan vermektedir. Narktabtee ve Patpanichchot (2011) tarafından yapılan çalışmanın bulguları, UFRS uygulanmasının raporlanan rakamların işletme değeri ile daha fazla ilişkili olmasını sağladığını; ancak yatırımcı korumasının zayıf olduğu bir çevrede faaliyet gösteren ya da işletme yönetiminin takdir yetkisini yüksek miktarda kullanmasına açık olan işletmelerde (küçük işletmeler, nakit akışı ve satış rakamları çok dalgalanma gösteren ve daha 
çok zarar açıklayan işletmeler gibi) bu durumun değiştiğini göstermektedir. $\mathrm{Bu}$ durum, standartların uygulanmasında zorlayıcı bir güç olarak yasal sistemin önemini artırmaktadır (Soderdstorm ve Sun, 2007: 680). Benzer çalışmalar, muhasebe standartlarının ve yasal çerçevelerin uygulanmasının zorlanması; uyulmaması durumunda ise soruşturma açılması yoluyla UFRS ile daha fazla uyum sağlanacağını ve bunun da muhasebe kalitesini artıracağını savunmaktadırlar (Kothari, 2000: 4; Hope, 2003: 246).

UFRS ile uyumlu finansal raporlamaya geçiş taraftarları yatırımcıların sunulan bilgilere güvenindeki artışı ve uluslararası borsalarda işlem gören işletmeler açısından raporlama maliyetinin azalmasını potansiyel faydalar olarak görmektedirler.

Özetle, muhasebe sistemi ülke koşullarında organik olarak ortaya çıkan ve gelişen sistemlerdir. Bu nedenle, standardizasyonun bütün ülkeler için finansal raporlama kalitesini artıracağı kesin olarak söylenememektedir. Yatırımcıların iyi korunduğu ve işletmelerin de manipülasyonu engelleyici yönde özelliklere sahip olduğu durumlarda, UFRS ile uyumlu finansal raporların işletme değerini daha iyi yansıtması beklenmektedir. Yöneticilere daha fazla takdir yetkisi sağlanan ve yatırımcı korumasının güçsüz olduğu çevrelerde ise muhasebe bilgisinin değerle ilişkisi çok sağlam olmayabilmektedir. Özellikle UFRS'nin içerdiği gerçeğe uygun değer muhasebesi, yöneticilerin gerçeği yansıtabilmek üzere mesleki yargılarını kullanmalarını gerektirmektedir. Bu durum, işletme yöneticilerine manipülasyona açık daha fazla alan bırakmaktadır. İşletmeye özgü özelliklerin finansal raporlama kalitesi üzerinde etkisi olduğu düşünüldügünde, UFRS ile uyumlu finansal raporlama yapıyor olmanın tek başına finansal raporlama kalitesinin yüksek olduğu anlamına gelmediğini söylemek mümkündür.

\section{SONUÇ}

Bir bilgi sistemi olarak muhasebenin temel amacı ekonomik karar alıcılara aldıkları kararlarda kullanmaları üzere işletmenin finansal durumuna, finansal performansına ve finansal durumundaki değişimlere ilişkin bilgileri sunmaktır. Bu bağlamda, sunulan bilginin kullanıcılar açısından yararlı olacak şekilde sunulmuş olması gerekmektedir. Uluslararası Finansal Raporlama Standartları, Kavramsal Çerçeve'de de ihtiyaca uygun bilginin gerçeğe uygun şekilde sunulması gerektiği yönünde açıklamalar bulunmaktadır. İşletmenin sunduğu bilginin kullanıcıları için yararlı olmasının kaliteli şekilde hazırlanması ve sunulması ile doğru orantılı olduğu kabul edilmektedir.

Finansal bilginin kalitesine ilişkin kesin bir tanım bulunmamakla birlikte, kullanıcıların bilgiden beklentileri doğrultusunda literatürde "muhasebe karı ile ekonomik kar arasında güçlü bir ilişki bulunması" ya da "kazanç yönetimi uygulanmayan, kayıpların zamanlı bir şekilde sunulduğu ve değer ilgisi yüksek olması" şeklinde tanımlanmaktadır. Finansal bilginin hazırlanması ve sunulması sırasında etkili olan faktörler de literatürde geniş biçimde araştırılmaktadır. Çalışmada da işletmelerin kontrolleri dışında gerçekleşen ancak finansal raporların kalitesi üzerinde etkili olması beklenen ülkelere özgü faktörler 
açıklanmaya çalışılmaktadır. Bu kapsamda yapılan literatür taraması sonucunda "kültür", "politik sistem", "finansal piyasaların gelişmişlik düzeyi", "sosyal ve ekonomik koşullar", "muhasebe altyapısı ve muhasebe meslek örgütleri”, "rekabet ortamı”, “yasal sistem”, "vergi sistemi”, ve "muhasebe standartları" ülkelere özgü faktörler olarak belirlenmektedir.

Çalışmada açıklanan bu faktörler ülkemizde raporlama yapan bütün işletmeler için geçerlidir. Ancak, söz konusu bu faktörlerin dikkatle ele alınmış olması finansal raporların kalitesi üzerinde etki etmesi mümkün olan bütün faktörlerin incelenmiş olduğu anlamına gelmemektedir. Bunun nedeni, finansal raporlamayı genel olarak etkileyen bu işletme-üstü faktörlerin yanı sıra işletmelerin kendi özelliklerinden ya da yönetimlerinden kaynaklanan olumlu/olumsuz faktörlerin bulunmasıdır. Bu konuda da oldukça geniş bir literatür oluşmuş olmasına rağmen, söz konusu faktörler çalışmanın kapsamı dışında kalmaktadır. Ülkemizde finansal raporlama konusunun yeterince detaylı incelenmesi açısından, işletmeye özgü faktörlerin de incelenmesinin faydalı olacağı düşünülmektedir.

\section{KAYNAKLAR}

Acar, D.- Özçelik, H. (2011) "Muhasebe Bilgilerinin Kalitesini Etkileyen Kritik Başarı Faktörlerinin Algılanma Düzeyleri: Muhasebe Yöneticileri Üzerine Bir Araştırma" Muhasebe Bilim Dünyası Dergisi, Sayı: 2, 239-273.

Baiman, S.- Verrecchia. R. E. (1996) "The Relation among Capital Markets, Financial Disclosure, Production Efficiency and Insider Trading". Journal of Accounting Research, 34, 1-22.

Ball, R.- Kothari, S.P.- Robin, A. (2000) "The Effect of International Institutional Factors on Properties of Accounting Earnings". Journal of Accounting and Economics, Say1: 29, $1-51$.

Balsarı Ç. K.- Dalkılıç A. F. (2007) "Kural Bazlı ve İlke Bazlı Finansal Raporlama Standartlarının Karşılaştırılması”. Muhasebe ve Denetime Bakış Dergisi, 22, 105- 118.

Barth, M.- Beaver, W.- Landsman, W. (2001) "The relevance of the value relevance literature for financial accounting standard setting: Another view". Journal of Accounting and Economics, 31, 77-104.

Barth, M.- Landsman, W.- Lang, M. (2008) "International accounting standards and accounting quality". Journal of Accounting Research, 46, 467-498.

Bushman, R.- Piotroski, J. (2006) "Financial reporting incentives for conservative accounting: the influence of legal and political institutions", Journal of Accounting and Economics, 42(1).

Callao, S.- Jame, J. (2010) "Have IFRS affected eamings management in the European Union?” Accounting in Europe, 7(2), 159-190.

Chaney, P.- Cooil, B.- Jeter, D. (2007) “A latent class model of earnings attributes”. Çalışma Metni, Vanderbilt University. 
Chen, H.- Parsley, D.- Yang, Y. (2008) "Corporate Lobbying and Financial Performance”. Çalışma Metni.

Choi, T. H.- Pae, J. (2011) " Business Ethics and Financial Reporting Quality: Evidence from Korea" Journal of Business Ethics, 103, 403 - 427

Christensen, H. B.- Lee, E.- Walker, M. (2008) "Incentives or standards: What determines accounting quality changes around IFRS adoption?” AAA 2008 Financial Accounting and Reporting Section Paper.

Cohen, D. A. (2003) "Quality of Financial Reporting Choice: Determinants and Economic Consequences" SSRN Working Paper Series. Aralı. http://dx.doi.org/10.2139/ssrn.422581

Correia, M. M. (2010) "Political Connections, SEC Enforcement and Accounting Quality". Rock Center for Corporate Governance at Stanford University Çalışma Metni No. 61

d'Arcy, A. (2000) "The degree of determination of national accounting systems - an empirical investigation" Schmalenbach Business Review, 52, 45-67.

Darrough, M.- Stoughton, N. (1990) "Financial Disclosure Policy in an Entry Game”. Journal of Accounting and Economics, 12, 219-243.

Dechow, P.- Dichev, I. D. (2002) "The Quality of Accruals and Earnings: The Role of Accruals Estimation Errors". The Accounting Review, 77, 35-59

Dechow P. M.- Schrand, C. M. (2004) "Earnings Quality, The Research Foundation of CFA Institute".

Demski, J. (1998) "Performance measure manipulation". Contemporary Accounting Research, 15, 261-285.

Dyck, A.- Zingales, L. (2002) "Private benefits of control: an international comparison" Basılmamış NBER çalışma metni, No. 8711.

Ertan, Y. "Türkiye Muhasebe Standartlarının Denetim ve Muhasebe Kalitesi Üzerindeki Etkisi: Bir Uygulama”, Uludağ Üniversitesi Sosyal Bilimler Enstitüsü (Yayınlanmamış Doktora Tezi). Bursa, 2011.

Fan, J.- Wong, T. J. (2002) "Corporate ownership structure and the informativeness of accounting earnings in East Asia". Journal of Accounting and Economics, 33, 401425.

Francis, J.- Olsson, P.- Schipper, K. (2006) "Earnings Quality" Foundations and Trends in Accounting, 1(4), $259-340$.

Gençoğlu, Ü. G.- Ertan, Y. (2012) “Muhasebe Kalitesini Etkileyen Faktörler ve Türkiye'deki Durum”. Muhasebe ve Finansman Dergisi, 1-24.

Gray, S. J. (1988) "Towards a Theory of Cultural Influence on the Development of Accouting System Internationally” Abacus, 24(1), 1-15. 
Gücenme, Ü. (2005) Mali Tablolar Analizi ve Enflasyon Muhasebesi, Aktüel Yayınları, İstanbul.

Hope, O. (2003) "Disclosure practices, enforcement of accounting standards, and analysts' forecasts: an international study". Journal of Accounting Research, 41, 235-272.

Jaggi, B.- Low, P. Y. (2000) "Impact of Culture, Market Forces and Legal System on Financial Disclosures" The International Journal of Accounting, 35(4), 495- 519.

Jara, E. G.- Ebrero, A. C.- Zapata, R. E. (2011) "Effect of international financial reporting standards on financial information quality". Journal of Financial Reporting \& Accounting, 9(2), 176- 196

Jeanjean, T.- Stolowy, H. (2008) "Do accounting standards matter? An exploratory analysis of earnings management before and after IFRS adoption” Journal of Accounting and Public Policy, 27(6), 480-494.

Kothari, S. P. (2000) "The role of financial reporting in reducing financial risks in the market' in building an infrastructure for financial stability",

http://www.bostonfed.org/economic/conf/conf44/cf44_6.pdf (Erişim Tarihi: 26.09.2013)

La Porta R.- Lopez De Silanes, F. (1998) “Capital Markets and Legal Institutions”

Leuz, C.- Nanda, D.- Wysocki, P. (2003) "Earnings management and investor protection: an international comparison" Journal of Financial Economics, 69, 505-527.

Narktabtee, K.- Patpanichchot, S. (2011) “The Impact Of Country-Level vs Firm-Level Factors On The Effectiveness Of IFRS Adoption: The Case Of European Union" International Business \& Economics Research Journal, 10(10), 79-92.

Nkundabanyanga, S. K.- Tauringana, V.- Balunywa, W.- Emitu, S. N. (2013) "The Association Between Accounting Standards, Legal Framework And The Quality Of Financial Reporting By A Government Ministry İn Uganda”. Journal of Accounting in Emerging Economies, 3(1), 65 - 81

Nobes, C.- Parker R. (2008) “Comparative International Accounting” 10. Bask1, Prentice Hall

Piotroski, J. (2003) "Segment Reporting Fineness and the Precision of Investors Beliefs" çalışma Metni, University of Chicago

Saudagaran, S. M.- Diga, J. D. (2000) "The Institutional Environment of Financial Reporting Regulation in ASEAN".

Soderdstorm, Naomi S.- Sun, Kevin Jialin, (2007), "IFRS Adoption and Accounting Quality: A Review", European Accounting Review, Vol. 16, No.4, ss. 675-702.

The International Journal of Accounting. Schipper, K. ve Vincent, L. (2003) "Earnings quality". Accounting Horizons, 17, 97-110.

Türkiye Muhasebe Standartları Kurulu, "Finansal Raporlamaya İlişkin Kavramsal Çerçeve”. 
Verrecchia, R. E. (1983) “Discretionary Disclosure” Journal of Accounting and Economics, 5, 179-195.

Wagenhofer, A. (1990) "Voluntary Disclosure with a Strategic Opponent" Journal of Accounting and Economics, 12, 341-363.

Yu, F.- Yu, X. (2008) “Corporate Lobbying and Fraud Detection” Çalışma Metni

Zarb, B.J. (2006) "The Quest for Transparency in Financial Reporting" CPA Journal, 76(9), 30-33. 
